\title{
TOTAL PROTEIN AND CHOLESTEROL CONCENTRATIONS OF SPERMATOZOA AND FLUIDS DURING SPERM MATURATION IN BOVINE AND PORCINE MALES IN THE HUMID TROPICS
}

\author{
I. I. BITTO, E. C. UDOEKONG AND E. T. NYIJIR
}

(Received 21 September 2007, Revision Accepted 17 December 2007)

".".

\section{ABSTRACT}

The total protein and cholesterol concentrations of spermatozoa and fluids of regions of the reproductive tract during maturation were evaluated in white Fulani (Bunaji) bulls and indigenous West African boars using 12 healthy adult males of each species. Boars were superior to bulls in testicular spermatozoal total protein concentration $(p<0.05)$ while there were similarities between the species $(p>0.05)$ in the levels of protein in spermatozoa in other regions of the reproductive tract. There were likewise similarities between the species in the protein content of fluids in all the regions of the tract $(p>0.05)$. Whereas a significant drop in protein content of spermatozoa occurred in bulis $(p<0.05)$ from the testes to the epididymis; there were similarities $(p>0.05)$ in spermatozoal protein concentration between the testes and epididymis in boars. Epididymal spermatozoal protein levels were however significantly higher $(p<0.05)$ than corresponding values in the ductus deferens in both species. The cholesterol content of spermatozoa on the other hand differed significantly $(p<0.05)$ between the species in the testes, corpus and cauda epididymis as well as ductus deferens but had a similarity in the caput epididymis $(p>0.5)$. The concentration of choiesterol in testicular fluids were likewise similar $(p>0.05)$ between species in the caput but differed significantly $(p<0.05)$ between species in all other regions of the tract. Cholesterol levels in spermatozoa also significantly increased $(p<0.05)$ from the testes to the epididymis and significantly decreased $(p<0.05)$ from the epididymis to the ductus in both species. Testicular fluid cholesterol concentration dropped $(p<0.05)$ on entry into the epididymis in both species and declined through the epididymis and the ductus in bulls Significant increases $(p<0,05)$ were however found in the corpus and cauda epididymis. These results indicate the possibility of extending the semen of both species in the same media and also suggest species differences in the utilization of cholesterol by spermatozoa probably for the formation of cohesive membranes for their protection in this environment.

KEYWORDS: Bulls, Boars, Spermatozoa, Fluids, Protein, Cholesterol

\section{INTRODUCTION}

Testis function in mammalian species is dependent not only on the complex anatomy and series of developing germ cells (which eventually produce the male gametes) and the endocrinology of reproduction but also on the secretions of the male reproductive tract. After spermatogenesis in the seminferous tubules, spermatozoa are swept out through the rete testes into the epididymis in testicular fluid. Such spermatozoa however acquire motility and the capacity to fertilize eggs while in the epididymis through the proces 3 of maturation.

Several physiological, morphological and biochemical changes have been reported to be involved with sperm maturation (Voglmayr, 1975, White, 1980, Egbunike, 1995 and Osinowo, 2006). Some of such changes include the decrease in DNA, protein and phospholipids content of spermatozoa (White, 1980). The composition of epididymis fluid (which provides the environment for these changes) has been reported to be invoived in these processes (Orgebin - Crist et. al. 1976). Considering the important contributions of rete testis fluid, epididymal fluid and secretions of the accessory sex organs to semen and male fertility, their chemical compositions have for long been well documented for temperate breeds of farm animals (Vogalmayr et. al., 1976, Byar, 1975 and White, 1980). Similar reports in tropical breeds of livestock are lacking.

This work was therefore undertaken to provide information on the changes in total protein and cholesterol concentrations of spermatozoa and fluids during sperm maturation in White Fulani (Bunaji) Bulls and Indigenous West Afica Boars in a lowland humid tropical environment.

\section{MATERIALS AND METHODS}

\section{Location}

This study was conducted in Makurdi, Nigeria located at latitude $7^{\circ} 14 \mathrm{~N}$ and longitude $8^{\circ} 31 \mathrm{E}$, with an annual rainfall ranging from $1270-1397 \mathrm{~mm}$ and a temperature range of $21^{\circ} \mathrm{C}-42.6^{\circ} \mathrm{C}$

\section{Sample Collection}

Reproductive tracts of matured White Fulani (Bunaji) bulls and indigenous West African boars were coliected intoto between 0600 and $0700 \mathrm{~h}$ from the Modern Market and Wurukum Abattoirs and brought to our laboratory at the University of Agriculture Makurdi in insulated ice - boxes. A total of 13 sampies for the bulis and 12 samples for boars were randomly obtained while evaluations were done on 12 samples for each species

\section{Biochemical Analysis}

Each reproductive tract was weighed intoto after which the testes were carefully dissected out and trimmed free of adhering fat and connective tissue. Known weights of both left and right organs were placed in clean beakers and homogenized in $0154 \mathrm{~m} \mathrm{NaCl}$ as earlier reported (Bitto and Egbunike, 2006) Homogenization was accomplished by mincing and filtering through two layers of loosely netted bandage followed by separation of spermatozoa and fluids from the respactive regions of the reproductive tract as already reported (Bitto and Aroh, 2006) The samples were stored frozen immediately after separation pending biochemical assays.

The concentrations of total protein and cholesterol in testicular spemiatozoa and fluids were determined as already fully described cy bitto el al (2000a) 


\section{Statistical Analysis}

Data were subjected to the one way analysis of variance (ANOVA) between regions of the reproductive tract within species as well as the student " $t$ " test between species (Steel and Torrie, 1980).

\section{RESULTS AND DISCUSSION}

The total protein of spermatozoa and reproductive tract fluids are summarized in Tables 1 and 2 respectively Beside the significantly higher level of protein in spermatozoa in the testes of boars than bulls $(p<0.5)$, there were similarities between the species $(p>0.05)$ in the protein content of spermatozoa in all other regions of the reproductive tract. There were likewise similarities between the species in protein content of fluids in all regions of the reproductive tract $(p>0.05)$... While these results show species differences in spermatozoal total protein concentration (probably due to species differences in sperm concentration and the rate of utilization of amino acids by spermatozoa) the similarities between the species in the protein content of spermatozoa and fluids in other regions of the reproductive tract indicate similar changes in both species in aspects of the biochemistry of spermatozoa associated with ripening Also, whereas the total protein content of spermatozoa from the epididymal segments were respectively superior $(p<0,05)$ to those of the testes and ductus in bulls, both testicular and epididymal spermatozoal protein concentrations were similar $(p>0,05)$ and respectively superior to that of the ductus deferens $(p<0.5)$ in boars. There were however similarities between regions of the reproductive tract $(p<0.05)$ in spermatozoal total protein in fluids of the tract (Table 2). These results confirm species differences in regions of the reproductive tract with regard to some biochemical characteristics of spermatozoa during maturation (White, 1980). The similarities between the species in protein levels in the fluids of the tract on the other hand suggest that both species might require the same media for semen extension (Bitto el al, 2000b).

Table 1 The total protein concentrations of spermatozoa of Bunaji bulls and West Africa boars during sperm maturation $(\mathrm{g} / 100 \mathrm{ml}$ ) (means $\pm \mathrm{sem}$ )

$\begin{array}{lll}\text { Region of tract Bulls Boars } & \text { B }\end{array}$

$\begin{array}{lll}\text { Testes } & 0.24 \pm 0.05^{\mathrm{a}} & 1.05 \pm 0.04^{\mathrm{b}} \\ \text { Caput } & * 1.49 \pm 0.52 & 1.33 \pm 0.06 \\ \text { Corpus } & 0.95 \pm 0.19 & 1.45 \pm 0.08 \\ \text { Cauda } & 0.76 \pm 0.12 & 1.40 \pm 0.07 \\ \text { Ductus deferens } & * 0.33 \pm 0.07 & * 0.72 \pm 0.10\end{array}$

sem =Standard error of mean; $a, b,=a, b$,values in the same raw bearing different superscripts differ significantly $(p<0.05) ;=$ significant differences between regions of the tract $(p<0.05)$.

Table 2: The total protein concentration of fluids of the reproductive tract in Bunaji bulls and West Africa boars $((\mathrm{g} / 100 \mathrm{ml}) \text { (means } \pm \mathrm{sem})^{*}$

\begin{tabular}{lll} 
Region of tract & Bulls & Boars \\
\hline Testes & $0.32 \pm 0.08$ & $0.49 \pm 0.04$ \\
Caput & $0.51 \pm 0.05$ & $0.53 \pm 0.02$ \\
Corpus & $0.48 \pm 0.10$ & $0.76 \pm 0.06$ \\
Cauda & $0.74 \pm 0.34$ & $0.53 \pm 0.02$ \\
Ductus deferens & $0.51 \pm 0.18$ & $0.73 \pm 0.01$ \\
\hline
\end{tabular}

sem $=$ Standard error of mean; $\quad=(p>0.05)$.

Spermatozoal cholesterol levels (Tabie 3 ) were significantly higher $(p<0.05)$ in boars in the testes, caput, corpus and ductus deferens but significantly lower in boars $(p<0.05)$ in the cauda epididymis. Cholesterol levels in fluids were however significantly lower $(p<0.05)$ in the testes in boars, similar between the species in the caput $(p>0.05)$ but higher $(p<0.05)$ in the boar in the corpus, cauda and ductus deferens. These species differences would be expected going by earlier reports on the cholesterol content of epididymal and ejaculated spermatozoa in mammalian species (Quinn and White. 1967 and Darin-Bennett and White, 1975).

The significant increase in spermatozoal cholesterol content $(p<0.05)$ from the testes to the epididymis in both species is in contrast with earlier reports (Quinn and White, 1967 and Scott et al. 1967) in temperate regions. This disparity could be explained by the fact that cholesterol is known to be involved in cellular actions and functions (Locke, 1964). Iis importance in spermatozoa includes the formation of cohesive membranes against stress. The exposure of these animals to 
stress goes on all year round as high ambient temperatures here in the tropics impose environmental stress (Egbunike et al, 1985) on the testes (with concomitant effect on spermatozoa) during normal development and in adult life, especially in the extensive system of management from where the animals for this study were sourced. Cholesterol levels might therefore increase in spermatozoa during maturation, in the tropics to heip the cells withstand environmental stress, as the testes environment is highly sensitive to increases in temperature. The phenomenon may be explained further by the involvement of cholesterol with testosterone production. We in an earlier work (Egbunike et al ; 1999) found significantly higher testosterone levels in bucks in the hotter dry seasons of the year than in the cooler rainy seasons it does appear therefore that there is some alteration in the dynamics of androgen metabolism during hot weather and during heat stress in our environment especially as these animals had been reared extensively without proper shelter

There were however sianificant decreases in cholesterol levels in fluids in both species $(p<0.05)$ from the caput followed by a significant steady decline $(p<0.05)$ during maturation (as expected) in bulls but an increase in boars (Table 4).Even though we did not investigate the relationships between the spermatozoal and fluid fractions of cholesterol in the present study, it appears that the increase from the testes in spermatozoa had a corresponding decrease in the fluid. The utilization of cholesterol in the formation of cohesive membranes during heat stress and the dynamics of androgen metabolism during environmental stress might therefore be the determining fassurs in the proponions of cholesterol found either in sperntatozoa or fluid in the respective regions of the reproductive trat at any point in time. The testes in boars in the present study also appear to have been more sensitive to environmental stress than in bulis

\section{CONCLUSION}

This work demonstrates some differences between the Bovine and Porcine species in total protein and cholesterol concentrations of spermatozoa and fluids of the reproductive tract during speim maturation, and similarities between these species in this regard that suggest that the semen of both species may be extended in the same media in this environment. The results of this study also strongly imply an alteration in the expected changes in cholesterol concentration associated witr sperm maturation in temperate regions. Proper housing of these animals in our environment is recommended as it is expencted to enhance the fertility and optimal productivity of these species in their native tropical environment

Table 3: The cholesterol concentrations $(\mathrm{mg} / 100 \mathrm{ml}$ ) of spermatozoa of Bunaji bulls and West Africa boars during sperm maturation (means \pm sem)

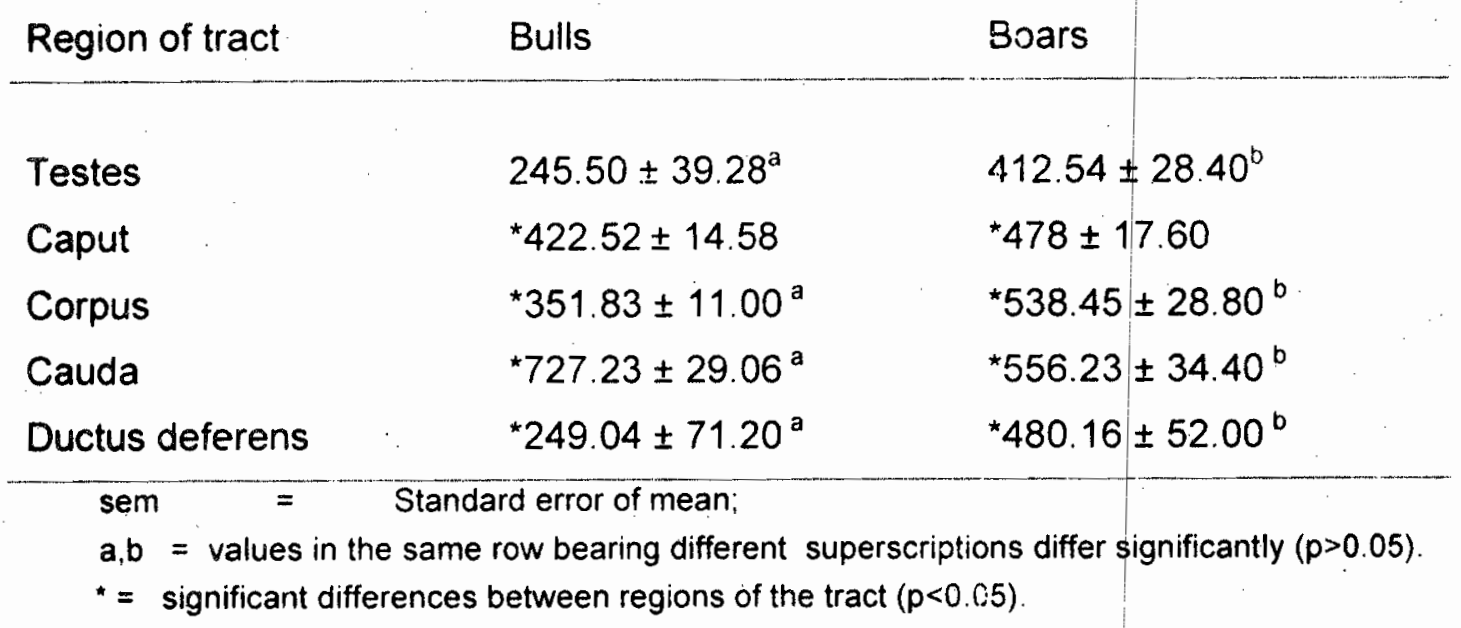

Table 4: The cholesterol concentration $(\mathrm{mg} / 100 \mathrm{ml})$ of fluids of the reproductive tract in Bunaji bulls and West Africa boars during sperm maturation (meanis \pm s.e.m.)

\begin{tabular}{lll}
\hline Region of tract & Bulls & Boars \\
\hline Testes & $627.10 \pm 35.51^{\mathrm{a}}$ & $492.96 \pm 42.20^{6}$ \\
Caput & $* 457.00 \pm 18.56$ & $* 471.19 \pm 26.60$ \\
Corpus & $440.80 \pm 19.67^{\circ}$ & $50.44 \pm 60.00^{\mathrm{b}}$ \\
Cauda & $413.60 \pm 93.90^{\circ}$ & $526.20 \pm 10.62^{\mathrm{b}}$ \\
Ductus deferens & $* 316.30 \pm 10.25^{\mathrm{a}}$ & $* 44.61 \pm 12.30^{\mathrm{b}}$ \\
\hline
\end{tabular}

sem $=$ Standard error of mean;a,b $=a, b$, values in the same row bearing ififerent superscriptions differ significantly $(p<0.05),=$ significant differences between regions of the tract $(p<0.05)$ 


\section{REFERENCES}

Bitto, 1 I. and Aroh, V. O, 2006. Testicular morphometry and some biochemical characteristics of testicular spermatozoa and fluid in Red Sokoto (Maradi) bucks. Global J. Agric. Sci. 5(1): $67-70$

Bitto, I. I., Sende, C. T, and Eze, P. U., 2000a. Preliminary investigations on the effect of cassava peel meal on Testicular morphometry and some biochemical characteristics of serum in Cockerels. Global Journal of Pure and Appt. Sci. 6(2): 161-165

Bitto, I. I., Akusu, M. O., Egbunike, G. N and Akpokodje, J. U., $2000 \mathrm{~b}$. A comparative study of spermatozoal abnormalities and some Biochemical characteristics of Ovine and Caprine semen in the humid tropics. Trop. J. Anim. Sci. 3(1): $169-174$

Bitto, I. I. and Egbunike, G. N., 2006. Seasonal variations in sperm production, gonadal and extragonadal sperm reserves in pubertal West African Dwarf Bucks in their native tropical environment. Livestock Res. For Rural Dev. 18(9) (Sept.2006) Article\#134. Retrieved November26, 2006 from http //unw cipav org co/lrd//rrd18/9bitt18134. htm

Byar, D.P., 1975, Zinc in male sex accessory organs Distribution and hormonal respons. In maie Accessory Sex Organs. D. Brands (ed). New York, Accademic, Press, Pp.169-171

Darin-Bennett, A and White, I G., 1975. Cholosterol and Phospholipid content of mammaliaian spermatozoa and its relation to membrane structure and cold shorch. J. report. Fertil. 43 $382-384$

Egbunike, G. N. Bitto, 1. 1., and Akusu, M. O., 1999. The effect of acute heat stress on circulation Testosterone level in West African Dwarf buck Trop. J. Anim Sci. 2(1). 223-229

Egbunike, $G N$, 1995. A toast for spermatozoa: One half the storey of mammalian life. An Iriaugural lecture. University of Ibadan. Ibadan (11 $11^{\text {th }}$ may, 1995).

Egbunike. G N. Togun, V. A and Agiang, , E. A., 1985
Sperm production in ruminants in hot humid climates. WId Rev Anim. Prod. XXI (3):11-17.

Egbunike, $G$. $N$ and Jeyakumar, $L$ H, 1980. Some biochemical characteristics of porcine seminal plasma under stressful hot humid climatic condition Zbl. Vet Med. A 27:555-562

Locke M. 1964. Cellular membrane in development. The $22^{\text {nd }}$ symposium of the Society for the study of development and growth. Academic press. New York

Orgebin-Crist, M. C. Danzo, B. J. and Cooper, T. G. 1976 Re examination of the dependence of the epididymal sperm viability on the eptdidymal environment. J. Rapred. Fertil. Suppl. 24:115.

Osinowo, O A., 2006. The Male Reproductive System. In Introduction to Animal Reproductive 1st (ed) Sophie Academic Services Ltd Abeokuta, Nigeria. PP. $15-20$.

Quinn, P. I and White, I G., 1967. Phospholipid and cholestrol content of epididymal and ejaculated Ram spermatozoa and seminal plasma in relation to cold shock. Aust J Biol Sci. 201205

Scott. T. W. Voglmayr, J. K and Setchell, B P. 1967 Lipid composition and metaboiism ti testicular and ejacuiated spermatozoa. Bioche J 102:456

Steel, R. G. D. and Torrie, J. H, 1980 Principles and Procedures of statistics. A Biometerical Approch $\left(2^{\text {nd }}\right.$ ed), Mc Graw Hill Book Company New York

Vogimayr, J K. 1975. Metabolic changes in spermatozoa during epididymal transit. In hand book of Physiology. Vol V.DW. Hamilton and R.O Greep (eds) Washington D C. American Physiological Society Pp 437-460

Voglmayr, J. K. Larsen, L $H$ and White, I G. 1970 Metabolism of spermatozoa and composition of fluid collected from the rete testis of living bulls J Reprod and Fertil 21:449-460

White, 1. G. 1980 Secretions of the maie reproductive tract anc seminal Plasma. In reproduction in farm Animal. ES E Hafaz (ed) $4^{\text {th }}$ ed 